\title{
Hirakud Dam Oustees and Procrastination of Justice in India
}

\author{
Ashok Dansana \\ School of Education, Ravenshaw University, Odisha, India
}

Corresponding author: dansana.cie@gmail.com

Received: 14-09-2020

Revised: $21-11-2020$

Accepted: 07-12-2020

\begin{abstract}
The Government of India had taken many developmental initiatives in the early years of independence and Hirakud Dam project was one among them, which was claimed as a milestone at that juncture and designed to serve multiple purposes of a substantial population in the State of the than Odisha. The initial phase of land acquisition and people displacement for the project was trouble ridden. The affected people staged agitations and shown their unwillingness for construction of dam on the river Mahanadi at Hirakud, Sambalpur. Despite of people resistance and indifferences they were persuaded for the greater causes and displaced with the assurance of immediate rehabilitation and adequate compensation for their sacrifices. In this paper an attempt has been done to make an account of existing circumstances and which also reveals the facts that there is serious abdication of the responsibility on the part of both, the Regional Government and Central Government. It is found that a large number of oustees of the project have not been restored and rehabilitated yet, even after nearly 75 years past to the commencement of the project. The nature of deprivation, stigma and social disintegration caused by displacement is found to be profound and widespread among the substantial population of Dam's oustees. The displaced have started developing a sense of distrust and hopelessness with a grave sense of disappointment and allegation against government. Lack of proper compensations and rehabilitation by the government has forced the displaced people to move to different places to settle themselves on their own initiatives. The recent attempts of measures by the Regional Government have been failed repeatedly simply because of inadequate approaches of government machineries. It is suggested that there are needs of more rigorous and holistic approaches of the State power to settle the long standing issue in a comprehensive manner.
\end{abstract}

Keywords: Hirakud Dam, Displacement, Rehabilitation and Development

Hirakud Dam is situated nearly 15 kilometres away from the Headquarter of Sambalpur district at Hirakud across the river Mahanadi in Odisha. Construction of the Damis claimed as a milestone on the onset of independence India. These days the Hirakud dam project has been devaluated to have failed on all fronts flood management, hydropower production, irrigation and navigation. It has been alleged for being responsible for socio-economic disintegration, deprivation, identity crisis and instability amongst the oustees (Nayak 2010 and Meher, 2011). The idea of Hirakud Dam project was potentially dynamic and productive since it was intended to serve multiple purposes of a substantial population in the State of the than Odisha but the circumstances clearly underpin that the Dam oustees have been grossly neglected and deprived from their legitimate rights by the State power till today,even after nearly 75 years

How to cite this article: Dansana, A. (2020). Hirakud Dam Oustees and Procrastination of Justice in India. Int. J. Soc. Sci., 9(04): 285-290.

Source of Support: None; Conflict of Interest: None (c) 9 
past to the commencement of the project. Primarily it was thought for flood management, hydropower production, irrigation and navigation. There were several justified reasons for construction of dam on the river Mahanadi at Hirakud. However, the initial phase of land acquisition and people displacement was trouble ridden. The affected people staged agitations and shown their unwillingness for construction of dam. Despite of people resistance and indifferences they were persuaded for the greater causes and displaced with the assurance of immediate rehabilitation and adequate compensation of their sacrifices. There are several accounts over the circumstances of post stage development. This includes a dark history of rehabilitation ventures and inadequacy in its fulfilment of the purposes as originally spelled out. Time and again the displaced people are organized under the banner of 'Hirakud Budi Anchal Sangram Samiti, which has been spearheading movements since long time for compensation for oustees of Dam Project but without adequate constructive outcomes. In 2020 the State Government had taken initiatives for restoration of the some displaced villages but could not do so due to compounding nature conflicts induced aftermath of Dam construction. One of the main reasons for failure in past initiatives is dispiritedness of local administrative machineries at the Block and District level and absence of holistic and rigorous approach of the Government of Odisha.

\section{Displacement and Rehabilitation}

Construction of dam induced a major displacement in undivided Madhya Pradesh and Odisha. Near about 100000 people excluding Madhya Pradesh were displaced in the than Odisha alone. The construction work of the dam starts in 1946 and completes in 1957. All land above River level (RL) 632 feet was acquired under the Land Acquisition Act, 1894 (Government of Orissa, 1968). By the time the construction was complete, it submerged 325 villages (291 villages in Odisha and 34 villages in undivided Madhya Pradesh) covering 183,000 acres of land, including 123,000 acres of cultivated land (Government of Orissa 2007). The Government of Odisha announced its rehabilitation policy as early as in the month of April 1946, when construction started commencing. The policy includes both the methods of cash compensation and physical rehabilitation. Compensation for lands likely to be submerged proposed in the feasibility report ranged from ₹ 50 to $₹ 1000$ per acre, according to their classification ${ }^{1}$ in terms of productivity. However, in reality, they were paid more or less at a rate ranging from ₹ 200 to ₹ 600 per acre, which was much lower than the market value. Similarly, the amount of compensation for submerged houses was too little and insufficient to construct a new home elsewhere (Government of India, 1947). Besides that each household willing to accept compensation in money would be paid the value of the land and house lost; and those who are willing to accept land and house in lieu of the land and houses lost would be provided land and houses. The government promised that the resettled villages would be provided with modern amenities like water, electricity and the re-settled evacuees would be vested with the proprietary right on the lands allotted to them. As a part of rehabilitation initiatives twelve colonies were set up for 28 villages.

However, as of now it is found that a substantial population nearly 26,000 families have not been properly neither compensated nor rehabilitated. The Government of Odisha had taken some compensatory financial measures at the end of nineteenth century, where few families were compensated with cash for their lost land at the rate ranging from ₹ 3000 to ₹ 4000 per acre as viewed by the displaced beneficiaries. After that almost two decades past to the last attempt in the name of measure the regional government paid partial attention to the long standing problem in the history of displacement in the country by virtues of some activisms exhibited at the individual and group levels. In this attempt the government planned to distribute the remaining land above 630 reservoir level amongst the originally displaced people and who are still living there with that limited cultivable land.

In the meanwhile there has been exponential growth of human population in these displaced villages due to internal and external factors. Internal factors such as people did not want to move outside in search of livelihood and land rather preferred to stay there. Since there was absence of ownership of land or restricted 
practices of land ownership stray people took the advantages of the ambiguities in ownership of land holding and somehow managed to settle there. The unregulated inflow of people to this unsettled area has made the situation more complex now. The State Government may be ready now to resolve the long standing problem but due to non-cooperative and confrontational behaviour of migrants and sometime of the natives it has really become a troublesome affair on the part of Government to deal with. And because of the lawlessness behaviour of people, both original habitants and migrants, the Government is seemed to be keeping distance at this moment by not taking clear stand with its enforcing machineries. However, the answer to the larger question is visible to all. After all who is responsible for the present state of conflict and unhappiness of these oustees, the clear answer is 'the State'. Therefore in the similar manner the State, here particularly the regional government has the legitimate power to act in more progressive, holistic and responsible manner rather remaining indifferent from the problem caused by itself. It is reported that in the recent time the government attempted to deal with the issue with its tehshil level officers and village members. However, due to deficient nature of their constitution of teams and power possession it has failed to address the problem. Keeping the complexity and graveness of the issue here the government should come out with more powered alternative. In this context some exclusive teams may be constituted at different tehshils comprising administrative head of tehshil, local self-government, senior members or eyewitnesses of displacement and members of law enforcing machineries such as local police officer. This teams should be given with maximum decision making power and must be acting in fair and prudential manner refraining themselves from undue influences and tainted gains in their positions and entrusted responsibilities.

\section{Deprivation, Livelihood and Socio Political Stigma}

The nature of deprivation and stigma is found to be profound and widespread among the Dam's oustees. Here the accounts of the first generation that is the immediate successors of the evictees and who had witnessed and been affected directly have been taken into consideration. Their narrations related to problems induced by mega project can be categorically understood interms of land holding, agricultural inputs, gain and loss, socio political withdrawal and stigma, instable sources of economy leading to abject poverty and inadequate schooling, higher education and availability of basic public amenities despite of occasional assurance in election manifesto. Deprivation has been an unabated and widespread cycle in the life of oustees. Agricultural practices were major sustainable sources of livelihood for the people prior to their displacement. They had substantial fertile household land possession and it was fairly distributed among them barring exceptional existence of land lord system. Paradoxically in present situation neither they possess ownership of even if a marginal piece of land nor do they have any sustainable source of livelihood. Fishing and forest collection although seems to be common visible practices among these people also often turn as highly vulnerable. People living in colonies and on the bank of reservoir also go for work to urban areas like IB Thermal Power Station located at Banharpali, Gumadera, Belpahar, Brajarajnagar, Jharsuguda, and Sambalpur on regular basis, where they are mostly engaged as unskilled wage labourer in hazardous conditions and in fewer cases they are employed as skilled work forces. Absence of ownership of land among these people leads to deprivation at manifold levels. Today a small unit of cultivable land (above 630 reservoir level) possessed by these people is treated as non-revenue and that is why they are not eligible for various government schemes available around. The displaced people feel dishonoured and deprived for not having minimum land holding, for being treated as encroachers and inability to avail the supports offered by the government to the people living in their own political structure, Panchayat Raj.

Now, they have started developing a sense of distrust and hopelessness with a grave sense of disappointment and allegation against government. Lack of proper compensations and rehabilitation by the government forced the displaced people to move to different places to settle themselves on their own initiative. It resulted in severe livelihood crises, health hazards and diseases 
have made them victims in their initial period of selfresettlement. Submergence of their lands under the Hirakud reservoir forced them to reel under various socioeconomic crises and marginalised them in various aspects of their life (Nayak, 2010). Balgovind Baboo (2009) reveals the fact that "some 4000 families have not received their compensation and it would be difficult to do so now as most of the records got destroyed". However, the people settled in the colonies are mostly depending upon forest collections and marginal agro products for their livelihood. As many as 34 displaced villages, which are treated as non-revenue, have been settled on the bank of reservoir mostly depend upon fishing and cultivation in the surplus land ${ }^{2}$. Fishing has been a major source of livelihood for the people these villages than cultivation. One of the dilemmatic state of affairs is these displaced families are now being treated as encroachers on the reservoir land. At the initial stage of resettlement on the surplus land the Water Resources Department used to lease lands to these farmers for cultivation on a yearly basis. The reservoir administration also discontinued leasing out this land for cultivation in recent years. These villagers have been helplessly struggling for getting revenue village rights and land rights of their settled land.

In 2005, the Government of Odisha decided to provide 0.10 acre of homestead land to the displaced people. However, there is very little progress in this regard. On 22 ${ }^{\text {nd }}$ August, 2011, the Revenue Minister of Odisha declared that non-revenue villages inthe peripheral region of the reservoir, falling between 630 to 632 Reservoir Levels will be regularised ${ }^{3}$. These villagers are presently described as encroachers and deniedbasic facilities for the last 53 years (Choudhury, Sandbhor, and Satapathy, 2012). At the time of construction of the dam, different traditions and cultures of the people of western Odisha were affected severely due to bitterness of displacement. The displaced people lost connections with their neighbourhood and community assets. Now due to diverting water to industries, livelihoods of thousands of farmers and fishermen are at stake (Thakkar, 2009). A typical incident of deprivation is foundin Tetiliabahal, a village of 15 families located in Banjari Panchayat of Jharsuguda district where all families come under below poverty line. There is no facility of electricity and drinking water. Children of the village walk up to seven kilometres for getting accessing to school education. Commenting on the plight of the displaced people Balgovind Baboo (2009) says"they felt completely alien in the new locality and suffered from the stigma of 'reservoir oustees'. Their overall life span was low as they suffered from mental trauma and hard physical work so essential to survive in the new places. Women suffered more than men and kids suffered from stolen childhood without proper schooling and merry-making". Participation in socio-political affairs which contributes in the productive development both at individual and collective level has been found to be restricted on the part of the displaced people. Often they have been encountered with profound nature of socio-political stigma. For instance if a person requires a residential or caste certificate from Tahasil Office he or she requires to be certified by Sarpanch, the Gram Panchayat Chief, where the concerned Sarpanch reveals the identity of the person. These practices often leave the people at the mercy of political chief at the local level governance. However, certification is not a requirement for a person having land ownership or patta on the other hand. Such circumstances create a sense of identity crisis, destitution and statelessness among oustees. Prior to displacement these people use to have substantial land possession adhered with self-sufficiency and esteem. But today they live at the sympathy of political chief and officials of the local government. The biggest question for all the evictees is why they should beg for their identity and certification of residential affiliation, which continue with them with honour and confidence before they were evicted? Why not they should be restored with minimum respect and care even after more than seven decades past to their sacrifice done for the larger public interest in the land of largest democracy? Oustees also narrate that due to indifferences to their identity they often prefer to withdraw themselves from taking participation in various socio-political affairs. This escalates further their impoverish condition. The abdicating state of affair is that the Government of Odisha claims that payment of ex-gratia compensation and distribution of homestead land, agriculture land, and land records of rights to the displaced people has been duly completed along with 
the provisions of basic amenities, when a fresh order was issued by the National Human Rights Commission acting on the petition filed by rights activist Radhakant Tripathyin May 2018, which eventually found to be a scandalous deception.

\section{CONCLUSION}

Displacement for larger public interest has been a welcome phenomenon in a democratic and welfare state like India, where the latter applies legitimate power on its people. Correspondingly when it comes to restoration and adequate rehabilitation of the displaced it has to be proactive and model of ethics and democracy. However, the past accounts and existing circumstances clearly suggest that there is a severe abdication of the responsibility on the part of both, the Regional and Central Government, in considering the voice and plight of the Hirakud Dam oustees, particularly those who are properly not restored and rehabilitated yet. The customary irresponsible behaviour of the Regional Government in particular is causing trust deficit among the displaced people.

In a democratic country like India ideally statehood and citizenship losses its legitimacy implicitly when its citizens do not get justice at time and need. The displacement related issues of Hirakud Dam Project particularly rehabilitation measure is a long standing opportunity on the part of India to prove itself as guardian of democracy. There is a well said proverb 'late is better than never'. These people might have developed a sense of great loss and distrust on State but nevertheless their trust can be restored and they can be rescued with their needs and in given challenging circumstances even after more than 75 years of hardship and grief in their life. Without further delay there is need of immediate constructive and holistic intervention on the part of the State Government so as these people can live a respectful life with a sense of political and social belongingness. As mentioned earlier the State Government has to address the issues on priority. Since it has become too late to address the problem in a comprehensive manner certain obvious situations such as land encroachment, distribution of available marginal land among the successors, political affiliation, social distance etc. have been developed by the passage of time and hence the Government has to develop need based strategies to deal with the complex nature of problem and moreover to restore faith on democracy in the land of world's largest democracy, India.

\section{NOTES}

1. The land was classified into six kinds based on its quality and productivity of soil. The land which had higher water absorbing and production capacity was given higher value and other. Most of land submerged in the reservoir was of high yielding and water absorbing capacity.

2. There was acquisition of land up to Reservoir Level $632 \mathrm{ft}$, and at some places up to RL $634 \mathrm{ft}$. When the FRL was finalized at $630 \mathrm{ft}$, a large chunk of land remained as surplus with the Water Resources Department in the peripheral region of the reservoir.

3. The Government of Odisha in 2011 decided to carry out a comprehensive survey of the villages falling between the heights of $630 \mathrm{ft}$ and $632 \mathrm{ft}$ above dead reservoir level and record the rights in favour of these villagers instead of the irrigation department.

\section{REFERENCES}

Baboo, B. 2009. Politics of water: The case of the Hirakud dam in Orissa, India. International Journal of Sociology and Anthropology, 1(8): 139-144.

Choudhury, P., Sandbhor, J. and Satapathy, P. 2012. Floods, Fields and Factories: Towards Resolving Conflicts around the Hirakud Dam, Pune: Forum for Policy Dialogue on Water Conflicts in India.

Government of India. 1947. Mahanadi Valley Development: The Hirakud Dam Project Central Waterways Irrigation and Navigation Commission, Simla: Government of India Press.

Government of Orissa. 1968. Report on the Benefits of Hirakud Irrigation: A Socio-Economic Study. Cuttack: Bureau of Statistics and Economics.

Himanshu, T. 2009. Hirakud Dam: Fifty Mournful Years. Dams, Rivers $\mathcal{E}$ People, 7: 5-7.

Meher, R. 2011. Big Dam, Big Failures: A Study of the Canal Irrigation System and Deprived Tail-End Farmers in the Hirakud Command Area of Orissa, India. Journal of Asian and African Studies, Sage, pp. 1-17. 
Nayak, A.K. 2010. Big Dams and Protests in India: A Study of Hirakud Dam. Economic E Political Weekly, 9: 69-73.

Pati, B. and Biswal, M. 2009. Hirakud Dam: Fifty Mournful Years. South Asia Network on Dams Rivers and People, 7: 7-11.
Viegas, P. 1992. The Hirakud Dam Oustees: The Thirty Years After in Thukral E.G. (ed.), Big Dam Displaced People: Rivers of Sorrow, River of Change, New Delhi: Sage. 